\title{
Interface learning: New goals for museum and upper secondary school collaboration
}

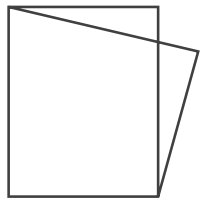

Sally Thorhauge, lektor, Horsens Gymnasium og Institut for Kommunikation og Kultur

\section{Afhandlingens fokus og mål}

Afhandlingens mål er at undersøge og analysere den læring, som foregår dels hos eleverne, dels hos lærerne og museumsinspektørerne i forbindelse med intrface-undervisningsforløb og samarbejde. intrface er en forening af gymnasieskoler og lokale museer i Danmark, som samarbejder i partnerskaber om at udvikle og gennemføre skolerelaterede, museumsbaserede undervisningsforløb for eleverne. Ph.d.-projektet fokuserer på den læringsoplevelse, som eleverne får i grænsefladen mellem de to læringsmiljøer: Gymnasieskolens formelle læringsmiljø og museets uformelle læringsmiljø. Fokus er også rettet mod lærernes og museumsinspektørernes oplevelse af læring gennem deres samarbejde. Afhandlingens mål er ydermere at demonstrere, om og hvordan partnerskabets samarbejde påvirker elevernes læring som følge af undervisningsforløbet. Afhandlingens ambition er at præsentere resultater, som partnerskaber mellem museer og skoler kan bruge til at udvikle potentialet af det læringsmiljø, som skabes i grænsefladen mellem skolen og museet. Forskningsspørgsmålene er som følger:

1. Hvordan påvirkes eleverne lœring af at gennemføre et undervisningsforløb, som inddrager museet som lœringsmiljø og som er blevet planlagt og implementeret gennem et samarbejde mellem lcerere og museumsinspektører?

2. Hvordan er gymnasielcreres og museumsinspektørers opfattelse af deres eget og deres samarbejdspartners praksisfœllesskab påvirket af deres samarbejde om at udvikle og gennemføre undervisningsforløb for eleverne, der inddrager museet som lœringsmiljø?

Forskningsdesign og analytiske metoder Afhandlingen er resultatet af en empirisk undersøgelse, som var organiseret efter et mixed methods forskningsdesign. Kvalitative data blev brugt som den primære kilde i forbindelse med analyse- 
og fortolkningsarbejdet og kvantitative data blev brugt som supplerende data i denne proces. De kvalitative data opstod gennem interviews med 29 elever, tolv lærere og otte museumsinspektører fordelt over fem casestudier. De kvantitative data indsamledes via to online spørgeskemaundersøgelser, som de deltagende elever besvarede. Den første stillede spørgsmål om deres forventninger til deres læring, inden de gennemførte undervisningsforløbet på museet, og den anden stillede spørgsmål til deres læringsoplevelser, efter de havde gennemført forløbet.

Generic Learning Outcomes (GLOs) blev brugt som den væsentligste metode til indsamling og analyse af både de kvalitative og de kvantitative data hidrørende fra disse læringsoplevelser. GLOs er et måle- og evalueringsværktøj, som blev udviklet i England i 2001-2002 og som gør det muligt at måle og evaluere museers og andre kulturarvsinstitutioners læringseffekt på gæsterne. GLOs er funderet i en bred definition af læring med baggrund i socialkonstruktivistisk læringsteori.

Amerikansk læringsteoretiker Etienne Wengers teori om praksisfællesskaber blev anvendt som den væsentligste metode til analyse af samarbejdet mellem intrface museer og gymnasier. Wengers læringsteori var velegnet til at anvende i analysen af elevernes læringsoplevelser på museet.

\section{Forskningens relevans}

Ph.d.-projektet har skabt viden om de læringsoplevelser, som gymnasieelever får ved at gennemføre skolerelaterede undervisningsforløb, der inddrager museet som læringsmiljø, om samarbejdet mellem gymnasielærere og museumsinspektører, som udvikler disse undervisningsforløb, om hvordan dette samarbejde påvirker læringsoplevelserne hos de elever, som gennemfører undervisningsforløbene samt om komplementariteten af formelle og uformelle læringsmiljøer. Ph.d.-projektet har vist, at intrface hvad angår mission, funktion, organisering og aktiviteter, både som projekt (2008-2011) og nu som forening - dvs. også de fem casestudie partnerskaber - lever op til mange af de regionale og statslige styrelsers anbefalinger og indsatsområder inden for kultur og uddannelse. Et væsentligt resultat af ph.d.-projektet er netop analysen af, hvordan den uddannelsespolitiske og kulturpolitiske udvikling siden strukturreformen og gymnasiereformen har skabt gunstige rammer for initiativer, der går på tværs af kultur- og uddannelsessektoren.

\section{Elevernes læring}

Hvad angår elevernes læring, viser ph.d.-projektets resultater, at elevernes motivation for at lære mindskes, og effektive læringsstrategier svækkes, når 1) undervisningsforløbet ikke er forberedt eller ikke skal bruges i forbindelse med igangværende skolearbejde, og når der ikke er et klart defineret formål med forløbet, 2) de ikke får feedback på deres arbejde og produkter, 3) de ikke får nok tid, eller de får for meget tid til at gennemføre forløbet, 4) lærerne er fraværende eller optræder udeltagende i forhold til aktiviteterne på museet, og 5) lærerne og/eller museumsinspektørerne ikke er fortrolige med forløbets struktur, indhold og formål.

Forskningsresultaterne viser, at selv om undervisningsforløbene i de forskellige casestudier var meget forskellige, var en generel respons fra intervieweleverne, at det var en lærerig oplevelse at gennemføre et undervisningsforløb, som foregik på museet. De var glade for afbrækket i den daglige rutine med undervisningstimer og for at være på museet; denne reaktion var forbundet med deres oplevelse af, at de fik større råderum på museet, end de normalt fik på skolen. Lærerne forbandt elevernes glæde med det uformelle læringsmiljø på museet. Elevernes glæde på museet var uafhængig af graden af samarbejde mellem lærerne og museumsinspektørerne. Men forskningsresultaterne viser også, at elevernes læring optimeredes væsentligt, når deres lærere og museumsinspektørerne samarbejdede om at skabe undervisningsforløb, som inkorporerede begge læringsmiljøers pædagogiske og didaktiske potentialer, praksisser og værktøjer, samt afsatte tilstrækkelig tid til at udvikle og gennemføre disse forløb. Eleverne, som oplevede den mest betydende læring inden for de fem GLOs, var dem, hvis arbejde stimuleredes af indre motivation. Deres indre motivation blev fremmet, hvis de fik en stor grad af dispositionsfrihed til selv at organisere deres arbejde. Dette øgede deres fornemmelse af selvbestemmelse og gav dem en følelse af ejerskab over arbejdsprocessen og slutproduktet. Når forløbet var organiseret således, at eleverne blev stillet autentiske spørgsmål og opgaver, og deres svar og produkter blev taget alvorligt af både lærere og museumsinspektører, var eleverne stærkt motiveret for at udføre forløbets opgaver. I nogle af casestudiernes forløb fik elevernes produkter tilmed et autentisk efterliv på museet. Ud over at være stærkt motiverende for eleverne støttede det participatoriske element af denne pædagogiske strategi deres evne til at reflektere over, forstå og tage ansvar for deres egen læring. I to af disse casestudier lykkedes det lærerne og museumsinspektørerne 
Tema: Tillid

at skabe et læringsmiljø, som legitimerede eleverne som kompetente medspillere såvel i deres egne grupper som på museet.

Forskningsresultaterne viser, at det ikke er elevernes identitet og agenda som elever, der skal udfordres, når de arbejder med et forløb på museet. Elevernes læring optimeredes, da de opdagede, at de autentiske spørgsmål, som de blev stillet, fordrede, at de anvendte deres vanlige læringsstrategier på en ny måde eller anvendte en bredere vifte af læringsstrategier, end de normalt brugte i forbindelse med tavleundervisning på skolen. Det at opdage, at deres læringsstrategier kunne tilpasses, eller at sjældent brugte læringsstrategier var effektive at anvende i det nye læringsmiljø, øgede deres selvtillid som lærende. Det at blive vurderet er en integreret del af undervisningen; ved at give eleverne muligheden for at blive vurderet uden for klasselokalet, hvor flere læringsstrategier kan tages i brug, gør det muligt for mange forskellige typer af elever at gøre sig fordelagtigt bemærket af lærerne og ikke kun dem, som normalt klarer sig godt i skolen.

Elevernes læring optimeredes, når de opgaver, de fik og de produkter, som de skulle lave tjente to formål: 1) som faglige opgaver og 2) som autentiske bidrag til museet. Dette animerede dem til at samarbejde, bandt deres aktiviteter på museum og skole sammen, styrkede deres forbindelse til museet og flugtede med deres agenda som elever.

\section{Årsagssammenhængen mellem elevernes} læring og partnernes samarbejde

Sammenligningen af analyserne på tværs af casestudierne illustrerede, at der var markant forskel på elevernes læringsoplevelser. Da disse forskelle sammenholdtes med resultaterne af analysen af lærernes og museumsinspektørernes samarbejde, blev det klart, at eleverne lagde mærke til og lod sig påvirke af, hvordan lærerne og museumsinspektørerne samarbejdede og af, hvor substantielt engagerede de var i undervisningsforløbet. Forskningsresultaterne viser desuden, at nedbrud i partnerskabernes kommunikation og internt på skole eller museum havde en begrænsende eller ugunstig indflydelse på elevernes læring.

\section{Partnerskabssamarbejde}

Forskningsresultaterne viser tydeligt, at kommunikation var nøglen til et vellykket samarbejde, både mellem partnerne og internt i den enkelte institution. Behovet for effektiv kommunikation var proportionelt med partnerskabets ambitionsniveau, og dette var bestemmende for, hvor meget tid og energi partnerne investerede i fællesopgaven at udvikle undervisningsforløb.

Barrierer for vellykket kommunikation og i sidste ende vellykket samarbejde og elevlæring skyldtes flere beslægtede faktorer, som for eksempel kollegers og øvrige medarbejderes ligegyldighed over for eller utilfredshed med den mængde tid og energi som partnerne investerede $i$ at udvikle og gennemføre undervisningsforløbet, forudfattede meninger om partnerinstitutionen som læringsmiljø og fastholdelse af konventionelle opfattelser hos både lærere og museumsinspektørerne af museets rolle som serviceleverandør. Forskningsresultaterne viser, at indledende dialogmøder og evalueringsmøder gav partnerne mulighed for at beskrive og diskutere, hvilke roller de ønskede at påtage sig i samarbejdet og i gennemførelsen af undervisningsforløb og derved undgå at opleve at blive sat ud på et sidespor. Endvidere var aktiv, opmærksom ledelsesstøtte i begge institutioner en vigtig medvirkende faktor til partnerskabets succes.

Forskningsresultaterne viser, at den enkelte partners læringsoplevelse på grænsen mellem de to praksisfællesskaber ikke alene gav ham indsigt i partnerens praksisfællesskab, men også et nyt syn på sit eget praksisfællesskab ved at opleve det fra partnerens perspektiv. Flere partnerskaber oplevede deres samarbejde som en praksisnær form for efteruddannelse.

Et vigtigt resultat af forskningen er, at hvis intrface-partnerskaber eller lignende partnerskaber ønsker at sikre optimal interface-læring for eleverne, må det mindset om, at skole-museum samarbejde er for tidskrævende og ressourcetung, ændres. Forskningsresultaterne viser, at dybden og bredden af elevernes læring inden for de fem GLOs var proportionel med partnernes investering af tid og energi $i$ alle faser af samarbejdet. 